Kajian Jurnalisme

ISSN 2549-0559 (cetak) ISSN 2549-1946 (online)

Volume 03 Nomor 01 Tahun 2019

\title{
Pemanfaatan Insta Story Dalam Aktivitas Jurnalistik Oleh Majalah Gadis
}

\author{
Cerysa Nur Insani, Dadang Rahmat Hidayat, Ipit Zulfan \\ Progam Studi Jurnalistik, Fakultas Ilmu Komunikasi, Universitas Padjadjaran \\ Email: cerysanurinsani@gmail.com
}

\begin{abstract}
Along with its process mediamorphosis has produced new technologies that can be used in communication. Instagram Story on Instagram is one of the product of technology development in communication. This feature offers convenience and speed that later is starting to get utilized by the media. Majalah GADIS is one of the mass media whom actively utilize Instagram Story on their Instagram for journalistic activities. This study aims to determine how Instagram Story is utilized in journalistic activities by Majalah GADIS. The result shows that Majalah GADIS decided to utilize Instagram Story for their journalistic activities because of its conformity with the targeted audience, accessibility, and effectiveness. The feature is used for three activities; as a reporting medium, as a tool to distribute information; and to interact with audience. The implications of the feature for Majalah GADIS are as an efficient and effective technology, easier way to connect with the audience, enhancement on traffic as a plus point on the business aspect, as an evaluation material for their content, and to prove Majalah GADIS'credibility as a media.
\end{abstract}

Keywords: digital journalism, instagram, insta story, journalistic activities, majalah gadis

\begin{abstract}
Abstrak
Dalam prosesnya mediamorfosis telah melahirkan teknologi-teknologi baru yang dapat dimanfaatkan manusia dalam bidang komunikasi. Fitur Insta Story dalam media sosial Instagram merupakan salah satu hasil perkembangan teknologi komunikasi. Kemudahan dan kecepatan yang ditawarkan oleh fitur ini kemudian mulai digunakan salah satunya pada bidang media. Majalah GADIS merupakan salah satu media massa yang aktif menggunakan fitur Insta Story pada akun Instagram mereka untuk aktivitas jurnalistik. Penelitian ini bertujuan untuk mengetahui bagaimana pemanfaatan fitur Insta Story dalam aktivitas jurnalistik oleh Majalah GADIS. Hasil penelitian menunjukkan bahwa pertimbangan Majalah GADIS memanfaatkan fitur Insta Story dalam aktivitas jurnalistiknya adalah kesesuaian dengan target khalayak, mudah diakses, dan efektif. Fitur Insta Story dimanfaatkan oleh Majalah GADIS untuk melakukan tiga hal yaitu; sebagai media pelaporan, sebagai alat distribusi informasi; dan sebagai wadah interaksi dengan khalayak. Implikasi pemanfaatan fitur Insta Story bagi Majalah GADIS adalah sebagai teknologi yang efisien dan efektif, komunikasi dengan khalayak lebih mudah, peningkatan jumlah kunjungan menjadi nilai tambah pada segi bisnis, sebagai bahan evaluasi mengenai konten, serta membuktikan kredibilitas Majalah GADIS sebagai sebuah media.
\end{abstract}

Kata kunci: aktivitas jurnalistik, instagram, insta story, jurnalisme digital, majalah gadis 
40 | Kajian Jurnalisme

ISSN 2549-0559 (cetak) ISSN 2549-1946 (online)

Volume 03 Nomor 01 Tahun 2019

\section{Pendahuluan}

Di era digital seperti saat ini, proses penyebaran informasi oleh media konvensional tidak lagi terpaku pada satu saluran utama. Sebagai salah satu upaya konvergensi, media konvensional juga memiliki akun media sosial sebagai tempat mereka menyebarkan informasi dan berinteraksi dengan khalayak. Salah satu media sosial yang banyak digunakan saat ini adalah Instagram. Instagram adalah media sosial yang memberi fasilitas bagi penggunanya untuk mengunggah foto dan video.

Tingginya jumlah pengguna media sosial di Indonesia menjadi dasar banyaknya media massa yang memanfaatkan media sosial sebagai saluran untuk penyebaran informasi. Hasil survey yang dilakukan oleh Asosiasi Penyelenggara Jasa Internet Indonesia (APJII) pada tahun 2018 menyatakan bahwa 87,13\% dari seluruh pengguna internet di Indonesia menggunakannya untuk mengakses media sosial (APJII, 2018). Data tersebut menguatkan pernyataan Instagram, yang dikutip oleh artikel berita tempo.co bahwa berdasarkan data internal Instagram, jumlah pengguna Instagram pada tahun 2017 meroket hingga 45 juta pengguna dari 22 juta pengguna di tahun 2016 (Tempo.co, 2017). Sri Widowati dalam wawancara dengan tempo.co juga menyatakan bahwa angka tersebut menempatkan Indonesia sebagai negara dengan pengguna aktif Instagram terbanyak di Asia Pasifik dan pembuat konten Insta Story terbanyak di dunia.

Pada Agustus 2016, Instagram meluncurkan fitur terbarunya yang bernama Instagram Story atau yang juga sering disebut dengan nama Insta Story. Fitur ini diperuntukkan bagi penggunanya untuk mengunggah foto atau video dengan durasi maksimal lima belas detik yang dinamakan dengan Story. Tampilan Story berbeda dengan foto reguler yang diunggah pada profil atau feed Instagram. Story ditampilkan secara kronologis di beranda Instagram dan hanya dapat dilihat selama 24 jam. Oleh sebab itu, Insta Story bersifat sangat aktual dan mudah diakses. Pada perjalanannya, Insta Story tidak hanya digunakan untuk pemilik akun individu, namun juga digunakan untuk berbagai kepentingan seperti dunia bisnis dan marketing. Insta Story dapat digunakan sebagai media pemasaran digital. Salah satu kelebihan media sosial sebagai media pemasaran adalah sifatnya yang interaktif, sehingga pemilik atau pengelola usaha dan konsumen dapat langsung berinteraksi (Kusuma \& Sugandi, 2019:30).

Melihat keunggulan tersebut, fitur ini mulai banyak digunakan oleh akun Instagram yang dimiliki oleh media konvensional. Salah satu bentuk penggunaan fitur Insta Story yang dilakukan oleh media-media konvensional adalah sebagai media pelaporan atau liputan langsung. Saat ini sudah ada banyak media yang melakukan kegiatan reportase menggunakan fitur Insta Story. Di antaranya yang ialah Cosmopolitan Indonesia, Dewi Magazine, ELLE Indonesia Magazine, Femina Magazine, Gogirl! Media, Harper's BAZAAR Indonesia, her world Indonesia, dan Majalah GADIS.

Selain dapat membagikan informasi dalam bentuk foto dan video, Insta Story juga memiliki fitur Swipe Up. Fitur ini berperan sebagai hyperlink, dimana pengguna dapat membagikan tautan lewat Insta Story yang bisa langsung dibuka oleh followers dengan menggesernya ke atas. Fitur ini juga ikut dimanfaatkan oleh media untuk membagikan tautan berita dari laman situs web mereka. Hal ini mengindikasikan bahwa Insta Story juga dapat menjadi saluran distribusi berita yang baru di mana berita menjadi semakin mudah diakses 
Kajian Jurnalisme

ISSN 2549-0559 (cetak) ISSN 2549-1946 (online)

Volume 03 Nomor 01 Tahun 2019

dengan cepat oleh khalayak karena dibagikan melalui medium yang lebih praktis yaitu media sosial.

Melihat adanya pemanfaatan media sosial Instagram yang demikian tinggi, hal ini menunjukkan bahwa fasilitas Insta Story tersebut telah menawarkan alternatif baru terhadap jurnalistik. Proses reportase dapat dilakukan dengan lebih singkat dan disiarkan kepada khalayak yang lebih tepat sasaran karena khalayak utamanya merupakan pengikut (followers) dari akun media sosial milik media itu sendiri. Selain itu fitur Swipe Up juga menjadikan Insta Story potensial digunakan sebagai medium distribusi informasi.

Kegiatan memanfaatkan media sosial sebagai penyebaran informasi merupakan inovasi dalam aktivitas jurnalistik. Secara teknis, jurnalistik adalah kegiatan menyiapkan, mencari, mengumpulkan, mengolah, menyajikan, dan menyebarkan berita melalui media berkala kepada khalayak seluas-luasnya dan secepat-cepatnya (Sumadiria, 2010). Hal ini serupa dengan kegiatan pemanfaatan fitur Insta Story yang dilakukan oleh majalah Gadis.

Berdasarkan pengamatan peneliti, media yang melakukan pemanfaatan Insta Story cukup tinggi adalah Majalah GADIS, pada akun Instagram mereka@GADISmagz. Selama bulan Juni 2018 Majalah GADIS memproduksi 56 konten Insta Story. Konten Insta Story Majalah GADIS juga memiliki karakteristik informasi yang lengkap pada caption. Selain itu, Majalah GADIS juga aktif menggunakan fitur Swipe Up untuk mengarahkan khalayak yang melihat Insta Story langsung ke halaman artikel yang berada di situs web mereka.

Majalah GADIS merupakan sebuah majalah dengan periode cetak per dua bulan. Selain versi cetak, Majalah GADIS juga memiliki situs web (https://www.gadis.co.id) yang diisi dengan berita-berita seputar gaya hidup setiap harinya. Cara ini merupakan salah satu strategi konvergensi yang dilakukan oleh Majalah GADIS sebagai upaya untuk tetap bisa memenuhi kebutuhan informasi khalayaknya setiap waktu. Begitu pula dengan memanfaatkan Insta Story pada media sosial Instagram. Teknologi pada media sosial, yaitu fitur Insta Story pada Instagram adalah sebuah media konvergensi.

Melihat gejala-gejala yang sudah dipaparkan di atas, menjadi menarik utnuk diteliti bagaimana Majalah GADIS dalam akun Instagram-nya yaitu@GADISmagz memanfaatkan Insta Story untuk aktivitas jurnalistik? Adapun, aspek-aspek yang akan ditelaah adalah pertimbangan media, pola kerja yang dilakukan, dan implikasinya bagi media.

Konsep utama yang digunakan untuk sebagai pisau analisis ialah konsep jurnalisme digital. Kawamoto mendefinisikan jurnalisme digital sebagai penggunaan teknologi digital untuk mencari, memproduksi, dan menyebarkan berita serta informasi kepada khalayak yang sadar teknologi (Kawamoto, 2003). Konsep ini digunakan untuk mengidentifikasi kegiatan pemanfaatan Insta Story dalam aktivitas jurnalistik. Teori Social Construction of Technology dari Wiebe Bijker dan Trevor Pinch juga digunakan untuk menganalisis bagaimana Majalah GADIS memaknai Insta Story sebagai sebuah teknologi.

\section{Metode}

Pendekatan yang digunakan dalam penelitian ini adalah pendekatan penelitian kualitatif. Definisi penelitian kualitatif disintesiskan oleh Moleong sebagai penelitian yang bermaksud 
42| Kajian Jurnalisme

ISSN 2549-0559 (cetak) ISSN 2549-1946 (online)

Volume 03 Nomor 01 Tahun 2019

untuk memahami fenomena tentang apa yang dialami oleh subjek penelitian (Moleong, 2017:6). Pendekatan ini sesuai dengan tujuan yang ingin dicapai yaitu untuk melakukan pemahaman mendalam, serta memahami proses dan makna pemanfaatan fitur Insta Story dalam aktivitas jurnalistik oleh Majalah GADIS.

Penelitian ini menggunakan studi deskriptif karena peneliti ingin memberikan gambaran yang rinci mengenai bagaimana Majalah GADIS memanfaatkan fitur Insta Story sebagai sebuah teknologi yang dapat digunakan dalam aktivitas jurnalistik. Tujuan tersebut selaras dengan kegunaan studi deskriptif yang bertujuan untuk menggambarkan, meringkaskan berbagai kondisi, berbagai situasi, atau berbagai fenomena realitas sosial yang ada di masyarakat yang menjadi objek penelitian, dan berupaya menarik realitas itu ke permukaan sebagai suatu ciri, karakter, sifat, model, tanda, atau gambaran tentang kondisi, situasi, ataupun fenomena tertentu (Bungin, 2011:68).

Pengumpulan data dilakukan melalui wawancara mendalam dengan tiga informan dari redaksi Majalah GADIS, observasi ke beberapa medium Majalah GADIS, studi kepustakaan, bahan visual dari beberapa medium Majalah GADIS, serta data online melalui situs web Majalah GADIS (https://www.gadis.co.id) dan juga situs lainnya yang terkait dengan penelitian ini.

Penelitian ini menggunakan teknik analisis data kualitatif yaitu, bekerja dengan data, mengorganisasikan data, memilah-milahnya menjadi satuan yang dapat dikelola, mensintesiskannya, mencari dan menemukan pola, menemukan apa yang penting dan apa yang dipelajari, dan memutuskan apa yang dapat diceriterakan kepada orang lain (Bogdan \& Biklen, 2007)

Peneliti menggunakan teknik triangulasi untuk menguji keabsahan data pada penelitian ini. Teknik triangulasi data yang peneliti gunakan adalah triangulasi metode. Triangulasi dilakukan dengan cara membandingkan informasi yang didapatkan melalui metode wawancara dengan informasi yang didapatkan dari hasil observasi, serta dengan membandingkan informasi yang didapatkan dari informan berbeda melalui metode yang sama yaitu wawancara, dengan beberapa pertanyaan mengenai hal yang sama.

Objek penelitian ini adalah pemanfaatan fitur Insta Story dalam aktivitas jurnalistik yang dilakukan oleh Majalah GADIS. Subjek penelitiannya ialah redaksi Majalah GADIS yang terlibat secara langsung dalam pemanfaatan fitur Insta Story dalam aktivitas jurnalistik. Informan kunci yang dipilih adalah Pemimpin Redaksi, Redaktur Eksekutif, dan Managing Editor.

Berdasarkan data yang terkumpul, peneliti akan menjelaskan secara dalam mengenai pertimbangan pemanfaatan fitur Insta Story dalam aktivitas jurnalistik oleh Majalah GADIS, pola kerja, serta implikasinya. Pada akhirnya analisis data akan menjawab identifikasi masalah dan menciptakan kesimpulan tentang pemanfaatan fitur Insta Story dalam aktivitas jurnalistik oleh Majalah GADIS. 
Kajian Jurnalisme

ISSN 2549-0559 (cetak) ISSN 2549-1946 (online)

Volume 03 Nomor 01 Tahun 2019

\section{Hasil dan Pembahasan}

\section{Pertimbangan Majalah GADIS dalam Memanfaatkan Insta Story}

Sejak Instagram meluncurkan fitur Insta Story pada pertengahan 2016, redaksi Majalah GADIS langsung memanfaatkan fitur tersebut, diawali sebagai media pelaporan. Menurut Maharani Legita selaku Managing Editor GADIS, fitur tersebut langsung digunakan karena dianggap sebagai media yang cepat dan paling mudah saat itu. GADIS pun kemudian memutuskan untuk terus memanfaatkan fitur Insta Story dalam aktivitas jurnalistiknya yang didasari oleh tiga pertimbangan. Pertama, GADIS menemukan adanya kesesuaian antara target khalayak mereka dengan pengguna Instagram. Berdasarkan survei rutin yang dilakukan setiap tahun oleh GADIS, khalayak Majalah GADIS merupakan perempuan berusia 13 hingga 30 tahun dengan jumlah dominan pada usia 15 hingga 17 tahun. Sedangkan berdasarkan tingkat pendidikan, memiliki rentang dari pelajar SMP hingga mahasiswa dengan jumlah pembaca yang didominasi oleh pelajar SMA.

Rentang usia tersebut masuk ke dalam kategori Generasi Z, yaitu generasi yang tahun lahirnya pada rentang tahun 1995 hingga 2010. Generasi ini juga dikenal dengan nama iGeneration atau generasi internet. Karakteristik generasi ini adalah sudah mengenal teknologi dan berhubungan dengan dunia maya sejak kecil yang secara tidak langsung mempengaruhi kepribadian mereka. Generasi Z rata-rata mengakses internet hingga 3-5 jam sehari dengan jumlah $90 \%$ melalui ponsel pintar. Adapun aplikasi yang paling banyak diakses oleh Generasi $\mathrm{Z}$ adalah Instagram dan Line (Tirto.id, 2017).

Majalah GADIS melihat ada yang unik dari pola khalayaknya dalam mencari serta mengkonsumsi informasi dari media. Pertimbangan pola mencari informasi oleh khalayak tersebutlah yang kemudian dijadikan dasar oleh Majalah GADIS menghadirkan diri pada medium-medium yang banyak digunakan oleh khalayaknya, termasuk fitur Insta Story. Dengan target khalayak tersebut, GADIS pun berusaha untuk menghadirkan diri pada medium di mana generasi tersebut berada.

Kedua, GADIS melihat kemudahan Insta Story untuk diakses dibandingkan dengan fitur lain pada medium digital mereka lainnya. Berdasarkan riset GADIS, 90\% khalayak GADIS mengakses laman situs web dan media sosial GADIS melalui ponsel pintar. Hal ini dijadikan dasar oleh GADIS untuk mengoptimalkan medium-medium yang dapat dengan mudah diakses melalui ponsel pintar. Dibandingkan dengan medium sosial media lainnya, yaitu Facebook dan Twitter, aktivitas GADIS di Instagram memang yang paling banyak mendapatkan feedback dari khalayak. GADIS menyadari bahwa hal tersebut memang karena generasi khalayak GADIS yang kini paling banyak menggunakan Instagram.

Medium lain yang juga digunakan oleh GADIS adalah Youtube. Medium ini memiliki kesamaan fungsi dengan fitur Insta Story yaitu sebagai wadah untuk mengunggah konten berbentuk video. Meskipun menggunakan keduanya, GADIS tetap mengakui bahwa Insta Story lebih aktif digunakan karena lebih mudah diakses. Kembali pada karakteristik khalayak GADIS yang mayoritas merupakan pelajar, khalayak tersebut memiliki hambatan yaitu kemampuan yang terbatas dalam memiliki kuota internet sehingga agak kesulitan untuk mengakses video yang berdurasi panjang di Youtube. Sebaliknya, video di Insta Story hanya berdurasi maksimal 
44 | Kajian Jurnalisme

ISSN 2549-0559 (cetak) ISSN 2549-1946 (online)

Volume 03 Nomor 01 Tahun 2019

15 detik sehingga lebih mudah untuk diakses oleh mereka. Sebagai solusi terhadap terbatasnya akses khalayak ke Youtube mereka, GADIS menanggulanginya dengan cara memperbanyak konten dalam bentuk video di Insta Story.

Ketiga, karena telah dirasa sesuai dengan target khalayak dan mudah untuk diakses, GADIS merasa bahwa Insta Story merupakan fitur yang efektif untuk digunakan. Oleh sebab itu, GADIS memutuskan untuk memaksimalkan fitur Insta Story untuk beberapa aktivitas jurnalistik mereka yang dianggap kompatibel dengan karakteristik fitur Insta Story. GADIS menggunakan fitur Insta Story setidaknya untuk tiga kegiatan jurnalistik yaitu pelaporan langsung, distribusi artikel, dan interaksi dengan khalayak.

Pertimbangan Majalah GADIS dalam memanfaatkan fitur Insta Story juga dapat dilihat sebagai motivasi yang datang dari segi ekonomi media. Dilihat dari perspektif ekonomi media, teknologi memegang peran penting dalam industri media. Industri media massa harus senantiasa mengikuti perkembangan teknologi. Jika tidak, eksistensi media massa sebagai industri akan tergilas oleh kemajuan dan perkembangan teknologi (Usman, 2009).

Hal itu pula yang dilakukan oleh Majalah GADIS. Keputusan Majalah GADIS untuk memanfaatkan fitur Insta Story merupakan langkah mengikuti perkembangan teknologi serta mengikuti pola pasar atau khalayak mereka dalam mencari dan mengkonsumsi informasi. Strategi ini dilakukan untuk mempertahankan pasar dan menghindari resiko tenggelamnya eksistensi Majalah GADIS sebagai media massa karena tidak dapat mengikuti gerakan pasar.

\section{Aplikasi Kegiatan Jurnalistik Menggunakan Insta Story}

Redaksi Majalah GADIS memanfaatkan fitur Insta Story untuk tiga jenis kegiatan jurnalistik yaitu; (1) sebagai media pelaporan langsung saat liputan, (2) sebagai alat distribusi informasi (artikel), dan (3) sebagai wadah interaksi dengan khalayak.

Pemanfaatan yang pertama, yaitu pada kegiatan pelaporan liputan. Sebagai media pelaporan langsung redaksi Majalah GADIS mewajibkan adanya liputan langsung melalui Insta Story untuk setiap liputan. Kegiatan liputan biasanya berupa liputan event yang sifatnya undangan. Selain itu, kegiatan atau aktivitas yang dilakukan oleh redaksi Majalah GADIS juga dilaporkan melalui Insta Story, misalnya behind the scene pemotretan untuk cover Majalah GADIS versi cetak, atau wawancara pendek dengan artis atau tokoh yang diundang oleh GADIS. Alasan GADIS mewajibkan setiap liputan untuk dilaporkan langsung melalui Insta Story adalah untuk mengejar aktualitas. Sebagai media gaya hidup, urgensi untuk menaikkan tulisan di situs web agak longgar sementara versi cetak hanya terbit setiap dua bulan, sehingga GADIS ingin mengejar aktualitas untuk membagikan informasi kepada khalayak lewat laporan langsung melalui Insta Story.

Alur kerja liputan pada redaksi Majalah GADIS dimulai sejak redaksi menerima undangan event untuk diliput. Setelah undangan diterima redaktur akan memberi penugasan kepada wartawan magang yang akan pergi meliput. Setelah itu redaktur memberikan briefing kepada peliput. Briefing meliputi event apa yang akan diliput, momen-momen apa saja yang harus dilaporkan melalui Insta Story, informasi apa saja yang harus dimuat dalam caption Insta Story, serta keperluan wawancara dengan narasumber bila ada. 
Sebelum peliput berangkat ke lapangan, redaktur akan memberikan akses ke akun Instagram Majalah GADIS dari ponsel pintar pribadi milik peliput. Hal ini dilakukan agar peliput dapat langsung merekam dan mengunggah Insta Story ke akun Instagram Majalah GADIS secara langsung saat liputan, tidak perlu mengirim ke redaktur terlebih dahulu. Hal ini dilakukan agar proses pelaporan dapat berjalan langsung, tanpa ada delay sedikit pun. Proses log in ke akun Instagram Majalah GADIS dilakukan oleh redaktur sehingga kerahasiaan password tetap terjaga. Oleh sebab redaktur tidak dapat melakukan pengecekan terlebih dahulu terhadap Insta Story yang akan diunggah oleh peliput, redaktur harus terus memantau kegiatan pelaporan langsung dari kantor agar dapat segera menegur apabila ada kesalahan atau kekurangan.

Setelah liputan selesai, peliput kembali ke kantor dan redaktur sesegera mungkin meminta peliput untuk log out dari akun Instagram Majalah GADIS pada ponsel pintar pribadi milik peliput. Setelah itu barulah peliput melanjutkan tugasnya yaitu memproses hasil liputan untuk output berita di situs web atau pun cetak.

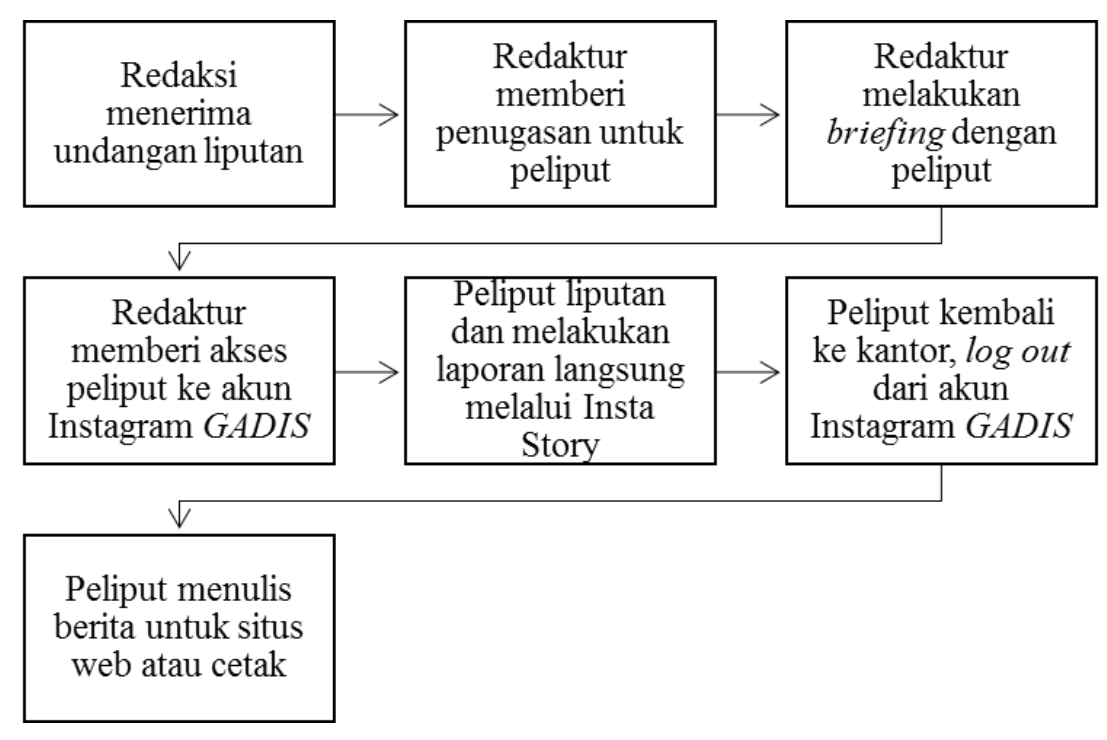

Diagram 1 Alur Pola Kerja Pelaporan Menggunakan Insta Story.

(Sumber: Analisis Peneliti)

Untuk beberapa liputan yang dianggap penting, GADIS mengabadikan laporan langsung dari liputan-liputan tersebut menggunakan fitur Highlights. Fitur Highlights adalah fitur yang dapat menyimpan Story pada profil pengguna Instagram agar Story tidak hilang setelah 24 jam, sehingga Story tersebut akan terus dapat dilihat oleh pengguna lainnya. Contoh liputan yang disimpan di Highlights pada Instagram Majalah GADIS adalah liputan selama rangkaian Asian Games 2018 dan rangkaian acara GADIS Sampul.

Sesuai dengan target khalayaknya yang mayoritas merupakan pelajar, waktu prime time di Instagram GADIS adalah di atas pukul dua siang atau setelah waktu pulang sekolah. Waktu prime time ini dijadikan pertimbangan bagi GADIS dalam melakukan aktivitas di Instagram. Namun untuk pelaporan liputan melalui Insta Story GADIS tetap langsung mengunggah sesuai 
46 | Kajian Jurnalisme

ISSN 2549-0559 (cetak) ISSN 2549-1946 (online)

Volume 03 Nomor 01 Tahun 2019

dengan kapan waktu acara diadakan. GADIS tidak menunggu prime time untuk mengunggah laporan langsung di Insta Story karena mengutamakan aktualitas dari acara yang diliput.

Pemanfaatan Insta Story sebagai medium distribusi informasi dilakukan oleh GADIS dengan menggunakan fitur Swipe Up yang tersedia di Insta Story. Fitur Swipe Up merupakan sebuah fitur eksklusif yang hanya dapat digunakan oleh akun yang telah terverifikasi oleh Instagram atau akun bisnis yang telah memiliki jumlah pengikut di atas 10.000. Fitur ini berperan sebagai hyperlink, dimana pengguna bisa menyertakan tautan ke halaman situs web lain lewat Story. Pengguna lain dapat dengan mudah membuka tautan ini hanya dengan cara menggeser Story tersebut ke atas dan akan langsung terarah ke halaman yang ditautkan. GADIS memanfaatkan fitur ini untuk mendistribusikan artikel mereka dari situs web. Selain artikel, fitur ini juga digunakan oleh GADIS untuk menyebarkan informasi mengenai kuis atau giveaway yang mereka adakan. Menurut GADIS, adanya fitur ini sangat membantu dalam menyebarkan artikel dan mengarahkan khalayak dari Instagram langsung ke situs web untuk menaikkan jumlah klik.

Artikel-artikel yang didistribusikan melalui Insta Story merupakan artikel-artikel yang diambil dari laman front image pada laman situs web Majalah GADIS. Dalam periode tertentu redaktur mengkurasi seluruh artikel yang dimuat pada situs web Majalah GADIS. Redaktur kemudian memilih beberapa artikel untuk ditampilkan pada front image laman situs web Majalah GADIS. Ditampilkannya artikel-artikel ini di front image dimaksudkan untuk menarik perhatian pengunjung situs web dan meningkatkan jumlah klik pada artikel-artikel tersebut. Indikator yang dijadikan standar dalam pemilihan artikel-artikel untuk ditampilkan pada front image adalah nilai berita yang sedang tinggi, seperti topik-topik yang sedang hits atau menjadi tren.

Artikel yang telah dipilih untuk berada pada front image kemudian didistribusikan juga melalui Insta Story. Tujuannya adalah agar khalayak di Instagram juga ikut tertarik dan langsung terarah ke situs web GADIS untuk menaikkan klik. Jika nilai berita pada artikel yang berada di front image cukup tahan lama, barulah GADIS juga akan mendistribusikannya lewat feed Instagram.

Dalam melakukan distribusi informasi menggunakan Insta Story baik untuk artikel maupun informasi kuis atau giveaway, GADIS memperhatikan waktu prime time pada Instagram Majalah GADIS. Hal ini karena tujuannya adalah untuk menarik perhatian sebanyak-banyaknya dari khalayak Majalah GADIS di Instagram, sehingga harus dilakukan pada waktu dimana khalayak banyak mengakses Instagram. 


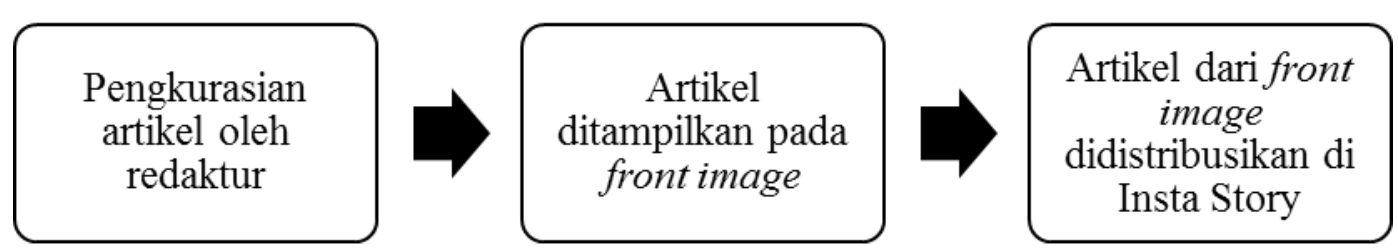

Diagram 2 Alur pola kerja distribusi artikel melalui Insta Story.

(Sumber: Analisis Peneliti)

Selain sebagai media pelaporan dan distribusi informasi, Majalah GADIS juga menggunakan fitur Insta Story sebagai sarana untuk berinteraksi dan membangun engagement dengan khalayak mereka. Hal ini dilakukan oleh GADIS karena mereka membutuhkan timbal balik dari khalayak mereka, sehingga GADIS berusaha untuk terhubung dengan khalayak salah satunya melalui fitur Insta Story.

Adapun bentuk interaksi dengan khalayak yang dilakukan oleh Majalah GADIS melalui Insta Story juga beragam. Ketika GADIS mengunggah Insta Story, khalayak dapat mengirimkan tanggapannya terhadap Story tersebut dan tanggapan tersebut akan masuk sebagai direct message ke akun Instagram Majalah GADIS. Direct message yang dikirimkan oleh khalayak biasanya berupa tanggapan atau pertanyaan yang berkaitan dengan konten Insta Story yang diunggah oleh Majalah GADIS. Dalam menanggapi tanggapan atau pun pertanyaan mengenai Insta Story mereka GADIS dapat menjawabnya atau memberi heart atau tanda suka terhadap tanggapan dari khalayak sebagai bentuk terima kasih atas respon yang diberikan oleh khalayak.

Penggunaan Insta Story sebagai wadah interaksi dengan khalayak juga dilakukan oleh Majalah GADIS saat melakukan pengumuman kuis atau giveaway. GADIS akan mengumumkan nama-nama pemenangnya lewat Insta Story, kemudian para pemenang dapat mengirimkan direct message ke Instagram Majalah GADIS sebagai bentuk konfirmasi. Setelah itu barulah GADIS mengontak para pemenang perihal pemberian hadiah kuis atau giveaway. Gambar berikut ini merupakan contoh pengumuman pemenang kuis melalui Insta Story. 
48 | Kajian Jurnalisme

ISSN 2549-0559 (cetak) ISSN 2549-1946 (online)

Volume 03 Nomor 01 Tahun 2019

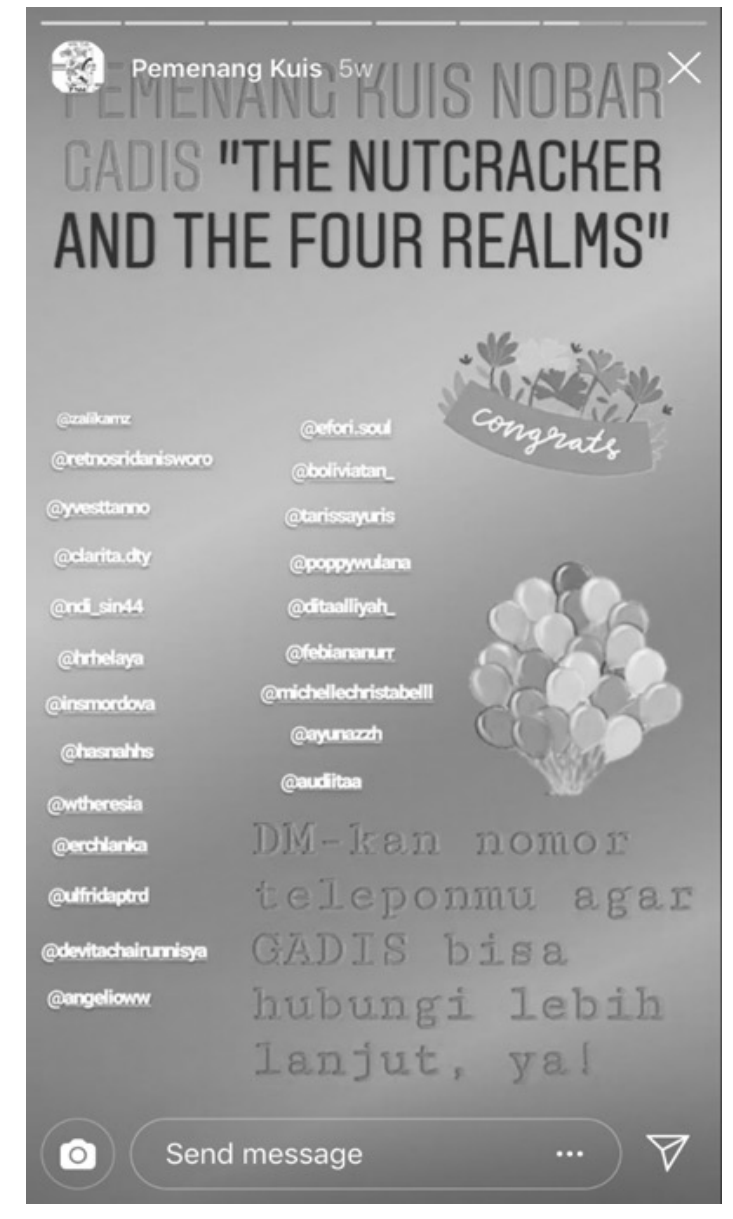

Gambar 1 Pengumuman pemenang kuis oleh Majalah GADIS melalui Insta Story.

(Sumber: Instagram Majalah GADIS)

Selain interaksi melalui direct message, pada momen-momen tertentu Majalah GADIS juga melakukan reshare atau pembagian ulang terhadap Insta Story dari khalayak yang menyebutkan username Instagram Majalah GADIS. Salah satu contohnya adalah ketika Majalah GADIS memperingati hari jadinya pada tanggal 19 November. Pada hari itu banyak pembaca Majalah GADIS yang mengunggah Insta Story untuk mengucapkan selamat hari jadi kepada Majalah GADIS, kemudian GADIS melakukan reshare melalui Insta Story di akun Instagram Majalah GADIS.

Pada beberapa kesempatan lain, GADIS juga menggunakan fitur lain yang ada pada Insta Story seperti memberikan polling yang dapat diisi oleh khalayak. Hal ini dilakukan agar konten Insta Story Majalah GADIS lebih variatif, tidak membosankan, dan dapat meningkatkan interaksi dengan khalayak lewat Insta Story.

Selain dari khalayak, GADIS juga kerap mendapatkan tanggapan dari tokoh atau musisi yang mereka liput. Ketika Majalah GADIS menyebutkan username Instagram tokoh atau musisi dalam laporan melalui Insta Story, tokoh atau musisi yang diliput kerap memberikan tanggapan baik dalam bentuk direct message kepada Majalah GADIS atau melakukan reshare pada akun mereka. 
Kajian Jurnalisme

ISSN 2549-0559 (cetak) ISSN 2549-1946 (online)

Volume 03 Nomor 01 Tahun 2019

\section{Strategi Cross Media dan Jurnalisme Digital dalam Pemanfaatan Insta Story}

Setelah melakukan liputan yang disertai dengan liputan langsung lewat Insta Story, peliput Majalah GADIS tetap bertanggung jawab untuk mengolah hasil liputan menjadi output berbentuk tulisan baik untuk cetak mau pun situs web. Umumnya setiap hasil liputan harus diolah menjadi tulisan di situs web, tetapi jika liputan dilakukan dalam jangka waktu mendekati tanggal cetak atau materi dari acara yang diliput bersifat tahan lama, besar kemungkinan tulisan hasil liputan tersebut akan dimuat di versi cetak. Oleh sebab itu, fungsi pelaporan melalui Insta Story bagi GADIS hanya untuk menyampaikan informasi-informasi pokok mengenai acara yang diliput secara aktual kepada khalayak. Pada akhir laporan langsung melalui Insta Story pun $G A D I S$ akan menginformasikan kepada khalayak untuk membaca artikel selengkapnya di situs web GADIS.

Hal tersebut merupakan salah satu bentuk dari strategi cross-media yang dilakukan oleh Majalah GADIS. Strategi cross-media adalah pendistribusian konten di lebih dari satu jenis media atau pada berbagai jenis perangkat penerima yang berbeda (Tassel \& Poe-Howfield, 2010:351). Berubahnya kebiasaan konsumsi informasi oleh khalayak membuat perusahaan media sebagai penyedia konten informasi harus menyasar khalayak mereka pada medium apa pun yang digunakan oleh khalayak. Keberhasilan strategi cross-media bergantung pada kesesuaian antara pilihan media yang digunakan dengan konten yang disajikan.

Menciptakan konten untuk medium yang berbeda dengan format, perangkat, dan khalayak berbeda artinya konten juga perlu disesuaikan dengan medium yang berbeda-beda tersebut. Pola yang banyak dilakukan oleh perusahaan konten dalam memenuhi kebutuhan tersebut adalah "create once, publish everywhere". Oleh sebab itu konten harus bersifat fleksibel dan dapat disesuaikan dengan banyak target khalayak pada medium berbeda.

Redaksi GADIS melakukan penyesuaian tersebut dengan mengolah informasi hasil liputannya menjadi tiga jenis output yaitu berupa laporan secara langsung di Insta Story, tulisan di situs web, dan tulisan di cetak dengan pertimbangan nilai berita. Majalah GADIS membagi tiga jenis output liputannya berdasarkan kedalaman. Tulisan di versi cetak memiliki tingkat kedalaman yang paling tinggi, paling lengkap, dan paling komprehensif mengingat adanya keleluasaan waktu dalam pengerjaan. Tulisan di situs web meskipun tidak sama komprehensifnya dengan cetak, tetapi tetap informatif dan easy-reading mengingat pembacanya berupa anak muda yang kebanyakan mengakses lewat ponsel pintar. Sedangkan Insta Story lebih singkat lagi dan hanya memberi informasi-informasi pokok karena dilakukan secara cepat dan langsung. Pertimbangan tersebut berdasarkan kesesuaian antara kedalaman berita dengan media yang digunakan serta perbedaan pola konsumsi informasi khalayak yang mengakses GADIS melalui Instagram, mengunjungi situs web, dan membaca versi cetak.

Majalah GADIS juga menggunakan Insta Story sebagai medium distribusi informasi. Penggunaan ini merupakan langkah yang lazim digunakan oleh media tradisional di era jurnalisme digital. Kevin Kawamoto dalam Digital Journalism: Emerging Media and the Changing Horizons of Journalism menjelaskan bahwa di awal kemunculannya, divisi online atau digital dalam suatu perusahaan media tradisional justru seringkali dianggap sebagai kompetitor atau ancaman bagi media cetak atau tradisional (Kawamoto, 2003). Namun seiring 
50| Kajian Jurnalisme

ISSN 2549-0559 (cetak) ISSN 2549-1946 (online)

Volume 03 Nomor 01 Tahun 2019

dengan waktu, mulai jelas bahwa hubungan antara media tradisional dan digital yang berada dalam organisasi berita atau perusahaan media yang sama bersifat simbiotik. Media cetak sudah mulai menyadari bahwa industri mereka mengalami penurunan, terutama terhadap generasi muda yang lebih aktif mencari informasi. Oleh sebab itu perusahaan media cetak harus menggunakan sejumlah inovasi teknologi, ekonomi, dan organisasi untuk tetap bertahan.

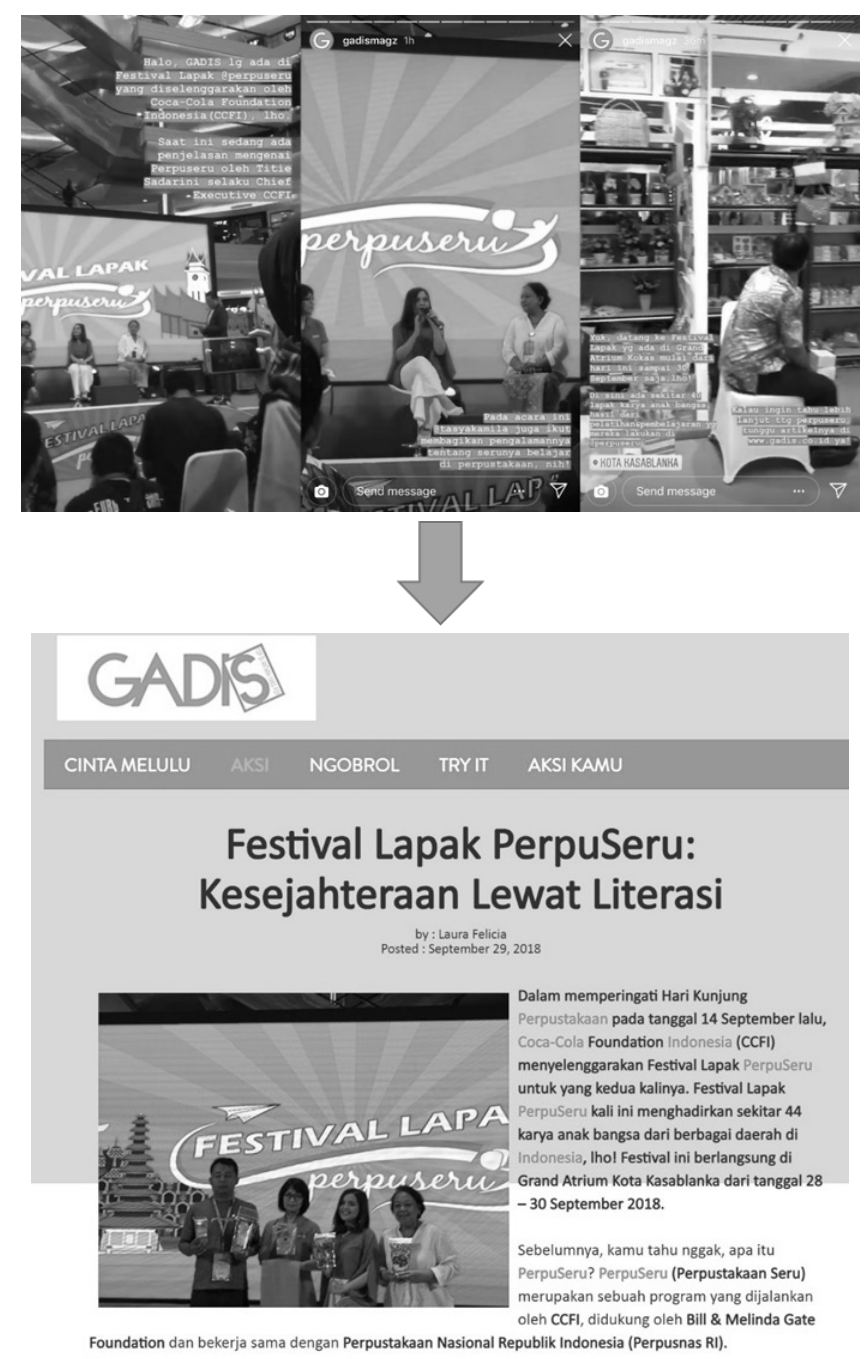

Gambar 2 Hasil tulisan di situs web dari liputan yang telah dilaporkan langsung melalui Insta Story pada tanggal 28-29 September 2018.

(Sumber: Instagram dan situs web Majalah GADIS)

Kemudian yang terjadi adalah media tradisional dan digital melakukan promosi silang satu sama lain dengan mengarahkan khalayak di antara keduanya sebagai bentuk kerja sama. Promosi silang antara media tradisional dan digital dalam satu organisasi atau perusahaan media merupakan cara konstruktif yang menunjukkan bahwa dua divisi ini dapat ada bersamaan, membantu satu sama lain untuk mengarahkan jumlah kunjungan khalayak. Dengan adanya kerja sama antar keduanya, dapat terlihat hubungan simbiotik antara media tradisional 
Kajian Jurnalisme

ISSN 2549-0559 (cetak) ISSN 2549-1946 (online)

Volume 03 Nomor 01 Tahun 2019

dan media digital yang akan bermanfaat bagi eksistensi satu sama lain dalam jangka panjang.

Promosi silang atau strategi cross-media yang dilakukan oleh Majalah GADIS juga dilakukan untuk mempromosikan versi cetak majalah mereka. Promosi ini tidak hanya dilakukan di Insta Story dan situs web saja, tetapi juga pada medium media sosial lain yaitu feed Instagram, Facebook, dan Twitter. Promosi ini dilakukan menjelang terbitnya versi cetak mereka untuk membangun antusiasme khalayak menyambut terbitnya versi cetak dan menarik perhatian khalayak agar tertarik membeli versi cetak majalah mereka.

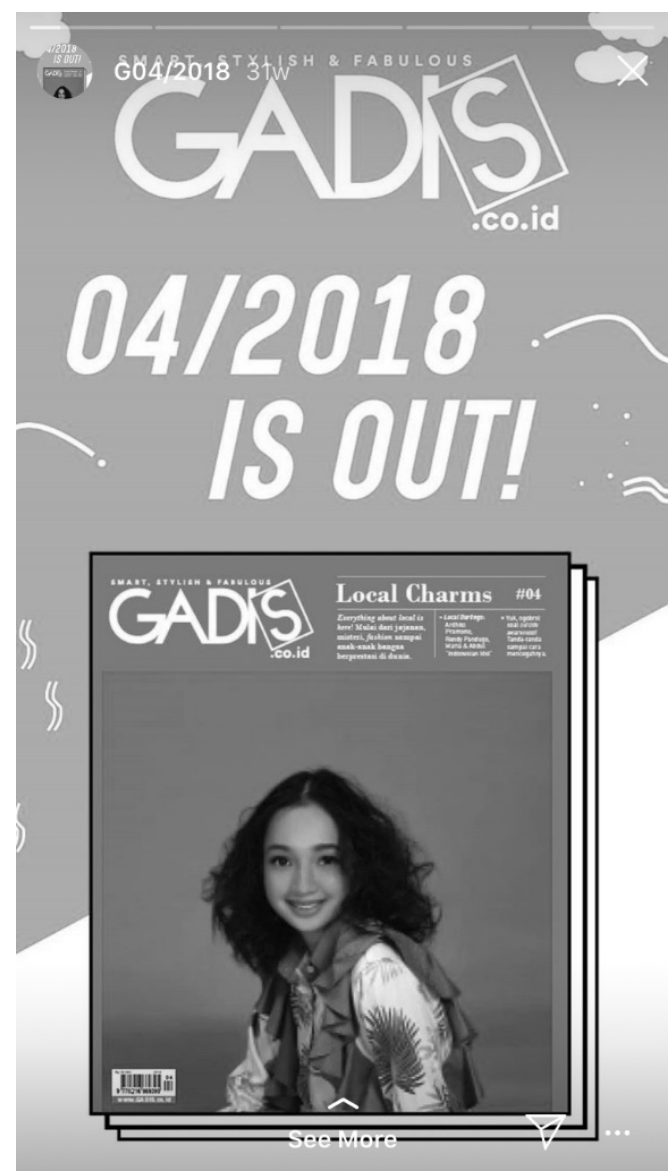

Gambar 3 Promosi versi cetak Majalah GADIS Edisi 04/2018 di Insta Story.

(Sumber: Instagram GADIS)

Dari segi efektivitas, Majalah GADIS mengakui bahwa kegiatan distribusi artikel dan informasi melalui Insta Story menuai hasil yang cukup efektif. Cara ini terbukti dapat meningkatkan jumlah klik pada halaman artikel dari situs web yang didistribusikan melalui Insta Story sekitar 20 persen jika dibandingkan dengan halaman artikel yang tidak didistribusikan lewat Insta Story. 
52| Kajian Jurnalisme

ISSN 2549-0559 (cetak) ISSN 2549-1946 (online)

Volume 03 Nomor 01 Tahun 2019

\section{Implikasi Pemanfaatan Insta Story bagi Media}

Pemanfaatan fitur Insta Story dalam aktivitas jurnalistik memberikan sejumlah implikasi bagi redaksi Majalah GADIS. Pertama, redaksi Majalah GADIS merasakan manfaat dari fitur Insta Story yaitu sebagai teknologi yang efisien dan efektif dalam membantu kerja mereka. Majalah GADIS menyatakan bahwa fitur Insta Story merupakan teknologi yang tepat digunakan berdasarkan khalayak yang mereka targetkan. Insta Story efisien dan efektif untuk digunakan karena banyak diakses oleh khalayak mereka, cepat, dan mudah untuk digunakan. Selain itu fitur yang ada dalam Insta Story yaitu Swipe Up juga membantu kerja Majalah GADIS dalam melakukan distribusi informasi.

Dilihat dari aspek ekonomi media implikasi ini merupakan dampak positif dari penggunaan teknologi terhadap industri media. Usman Ks. dalam bukunya Ekonomi Media Pengantar Konsep dan Aplikasi menyampaikan bahwa penerapan teknologi dalam industri media dapat menghasilkan pengaruh yang signifikan (Usman, 2009). Pengaruh ini akan dapat dirasakan oleh perusahaan media apabila menerapkan teknologi yang tepat dan sesuai dengan karakteristik media dan khalayak.

Usman Ks. menyampaikan bahwa pada gilirannya, teknologi dapat menciptakan efisiensi proses produksi sehingga memperkecil cost production, serta teknologi yang lebih efisien membuat pekerjaan di bidang informasi lebih produktif (Usman, 2009). Dalam kasus Majalah GADIS efisiensi proses produksi terjadi pada fitur Insta Story di mana satu fitur dalam satu aplikasi dapat membantu mengerjakan beberapa aktivitas jurnalistik sekaligus di antaranya laporan langsung dan distribusi informasi. Cara yang mudah dan proses cepat yang dapat dilakukan melalui Insta Story menjadikan fitur ini sebagai teknologi yang efisien dan memudahkan produktivitas Majalah GADIS dalam membuat dan menyebarkan konten atau informasi.

Implikasi yang kedua, berkaitan dengan segi bisnis media, peningkatan jumlah pengunjung atau jumlah kunjungan pada situs web Majalah GADIS yang disebabkan oleh distribusi melalui fitur Insta Story dapat menjadi nilai tambah yang dapat Majalah GADIS jual atau tawarkan kepada calon klien bisnis yang akan bekerja sama atau menaruh iklan pada situs web Majalah GADIS. Majalah GADIS juga dapat menawarkan promosi melalui Insta Story kepada calon klien bisnis mereka agar jumlah kunjungan yang didapatkan lebih tinggi.

Implikasi ini merupakan dampak positif yang didapatkan dari penerapan strategi crossmedia pada penggunaan fitur Insta Story oleh Majalah GADIS sebagai medium distribusi informasi. Salah satu tujuan dan fungsi dari strategi cross-media adalah menawarkan bentuk baru cross-promotion pada klien iklan yang mungkin menarik perhatian pada format iklan baru. Pada kasus ini selain menciptakan format iklan baru pada pengiklan, penggunaan fitur Insta Story oleh Majalah GADIS juga menjadi cara baru untuk meningkatkan jumlah kunjungan pada iklan yang dipasang oleh klien.

Ketiga, pemanfaatan Insta Story juga telah menjadi wadah yang membuat komunikasi antara Majalah GADIS dengan khalayak lebih mudah. Majalah GADIS dapat dengan mudah melakukan aktivitas yang melibatkan khalayak seperti kuis atau giveaway dan menyebarkan informasinya melalui Insta Story. Khalayak juga dapat dengan lebih mudah menyampaikan 
feedback-nya melalui Instagram Majalah GADIS. Dengan begitu Majalah GADIS dapat membangun kedekatan dengan khalayak mereka.

Kemudahan Majalah GADIS melakukan interaksi dan membangun hubungan dengan khalayak mereka sebagaimana disampaikan pada poin ketiga berhubungan dengan implikasi pemanfaatan Insta Story selanjutanya. Keempat, Feedback dari khalayak terkait konten Insta Story yang didapatkan oleh Majalah GADIS memudahkan redaksi Majalah GADIS untuk mengetahui artikel atau isu apa yang disukai oleh khalayak mereka. Feedback yang didapatkan terkait Insta Story ini kemudian dijadikan bahan evaluasi bagi redaksi Majalah GADIS untuk menentukan artikel mengenai apa yang perlu mereka buat atau topik apa yang perlu mereka bahas untuk memenuhi kebutuhan pembaca.

Hal ini sesuai dengan salah satu karakteristik jurnalisme digital yang disampaikan oleh Kawamoto yaitu interaktif, dimana karakter interaktif dalam jurnalisme digital berarti adanya proses pengikutsertaan manusia dan partisipasi mesin dalam proses mencari dan membagikan informasi (Kawamoto, 2003). Dalam jurnalisme digital penerima berita dan informasi tidak bersifat pasif. Mereka lebih pantas disebut sebagai "information seekers" atau pencari informasi, yang sudah terbiasa dengan pencarian dan strategi navigasi di internet.

Pada Instagram Majalah GADIS pun dapat dikatakan seperti itu karena khalayak secara sadar membuat pilihan dan melakukan tindakan untuk mengikuti akun Instagram Majalah GADIS dan melihat konten Insta Story Majalah GADIS. Setelah itu khalayak dapat mengirimkan tanggapan langsung ke akun Instagram Majalah GADIS sebagai bentukfeedback atau menginisiasi interaksi.

Kelima, implikasi pemanfaatan Insta Story dalam aktivitas jurnalistik oleh Majalah GADIS ialah membuktikan kredibilitas Majalah GADIS sebagai sebuah media. Berdasarkan hasil wawancara yang peneliti lakukan, ketiga informan mengeluarkan pernyataan bahwa penggunaan fitur Insta Story membantu Majalah GADIS membuktikan eksistensinya saat ini. Di era di mana banyaknya perusahaan media cetak yang terpaksa gulung tikar, Majalah GADIS masih membuktikan bahwa mereka masih mampu bertahan dengan cara menghadirkan diri dan aktif pada medium yang digandrungi oleh anak muda. Dengan begitu eksistensi Majalah GADIS sebagai sebuah media tidak hilang dan dapat tetap diakui. Contohnya, kegiatan melaporkan langsung melalui Insta Story dilakukan oleh Majalah GADIS untuk menunjukkan kepada khalayak bahwa Majalah GADIS merupakan media yang kredibel dan masih terlibat dalam liputan ke banyak acara-acara bergengsi, juga untuk menunjukkan bahwa Majalah GADIS masih konsisten memproduksi konten-konten yang informatif bagi khalayak.

Pernyataan mengenai implikasi tersebut peneliti analisis menggunakan teori konstruksi sosial teknologi atau Social Construction of Technology (SCOT). Teori yang dikemukakan oleh Trevor J. Pinch dan Wiebe E. Bijker (1993) ini berasal dari paradigma konstruktivis dan berpendapat bahwa bukan teknologi yang menentukan tindakan. Namun sebaliknya, tindakan manusia lah yang membentuk teknologi. Teori ini juga berpendapat bahwa cara teknologi digunakan tidak dapat dipahami tanpa memahami bagaimana teknologi tersebut tertanam dalam konteks sosial manusia (Bijker, Hughes, \& Pinch, 1993).

Terdapat dua poin penting dalam SCOT. Pertama, menurut teori SCOT tindakan 
54 | Kajian Jurnalisme

ISSN 2549-0559 (cetak) ISSN 2549-1946 (online)

Volume 03 Nomor 01 Tahun 2019

manusia lah yang membentuk dan menentukan teknologi, bukan sebaliknya. Kedua, setiap kelompok sosial berbeda dapat menginterpretasikan dan menggunakan sebuah teknologi dengan cara yang berbeda. SCOT memiliki kerangka konseptual yang terdiri dari komponenkomponen yang saling berhubungan. Komponen pertama dalam konsep SCOT adalah interpretative flexibility atau interpretasi fleksibel. Dalam interpretative flexibility, rancangan teknologi merupakan proses terbuka yang dapat memproduksi hasil akhir berbeda, tergantung keadaan sosial yang berlaku dalam perkembangan tersebut.

Dalam pemanfaatan fitur Insta Story oleh Majalah GADIS, Majalah GADIS sebagai sebuah media memiliki interpretasinya sendiri terhadap Insta Story sebagai sebuah teknologi dan memanfaatkannya berdasarkan interpretasi tersebut. Fitur Insta Story sebenarnya diciptakan oleh aplikasi Instagram sebagai fitur gaya hidup, yakni sekadar untuk membagikan informasi mengenai aktivitas sehari-hari pengguna kepada pengikut secara langsung. Namun Majalah GADIS sebagai sebuah perusahaan media melihat adanya potensi pada fitur Insta Story yang dapat dimanfaatkan untuk kepentingan mereka dalam melakukan aktivitas jurnalistik. Majalah GADIS kemudian menentukan aktivitas jurnalistik mereka yang relevan dan dapat dilakukan melalui fitur Insta Story, di antaranya yaitu melakukan laporan langsung, melakukan distribusi informasi, dan melakukan interaksi dengan khalayak. Pada tahap ini Majalah GADIS tidak lagi menginterpretasi fitur Insta Story sebagai sekadar fitur gaya hidup, tetapi merupakan alat yang dapat bermanfaat bagi aktivitas jurnalistik yang menguntungkan bagi mereka sebagai perusahaan media.

Komponen berikutnya dalam konsep SCOT adalah relevant social groups atau kelompok sosial yang relevan. Konsep ini merupakan wujud dari interpretasi "seluruh anggota dari kelompok sosial tertentu memiliki pemahaman makna yang sama, yang lekat dengan artefak tertentu" (Bijker et al., 1993). Pada pendekatan ini, merekalah agen di mana tindakan memanifestasi makna yang mereka berikan terhadap artefak.

Komponen ini berkaitan dengan bagaimana ketiga informan dalam penelitian ini yang merupakan anggota dari kelompok sosial yang sama, memiliki pemaknaan yang sama yang termanifestasi terhadap fitur Insta Story di mana makna tersebut terbentuk dari tindakan yang dilakukan oleh kelompok sosial mereka terhadap fitur Insta Story.

Setelah melakukan pemanfaatan terhadap fitur Insta Story dalam aktivitas jurnalistik sesuai dengan interpretasi kelompok mereka terhadap fitur Insta Story, ketiga informan sebagai anggota kelompok yang sama memiliki pemaknaan yang sama mengenai peranan Insta Story bagi keberlangsungan kelompok mereka yaitu Majalah GADIS sebagai perusahaan media. Ketiganya sepakat bahwa fitur Insta Story tak hanya mempermudah kerja jurnalistik mereka, tetapi juga sebagai alat pembuktian kredibilitas media mereka.

\section{Simpulan}

Pertimbangan Majalah GADIS memanfaatkan fitur Insta Story di Instagram dalam aktivitas jurnalistik adalah karena fitur tersebut dianggap sesuai dengan target khalayak yang mereka sasar yaitu Generasi Z, mudah untuk diakses oleh khalayak, serta merupakan fitur yang efektif digunakan. Pertimbangan-pertimbangan tersebut juga dapat dilihat sebagai motivasi 
dari aspek ekonomi media, yaitu mengikuti perkembangan teknologi karena mengikuti pola pasar atau khalayak mereka dalam mencari dan mengonsumsi informasi.

Majalah GADIS memanfaatkan fitur Insta Story untuk tiga aktivitas yaitu sebagai media pelaporan langsung, sebagai medium distribusi informasi, dan sebagai wadah untuk berinteraksi dengan khalayak. Pemanfaatan sebagai media pelaporan langsung dilakukan dengan tahap penugasan, briefing, pemberian akses Instagram, peliputan dan laporan langsung, log out, kemudian peliput mulai menulis berita untuk situs web atau cetak. Pemanfaatan sebagai medium distribusi informasi dilakukan dengan kurasi artikel oleh redaktur, artikel terpilih ditampilkan pada front image situs web, kemudian didistribusikan di Insta Story. Pemanfaatan sebagai wadah interaksi dilakukan dalam bentuk direct message, pengumuman kuis atau giveaway, dan reshare.

Dalam memanfaatkan fitur Insta Story Majalah GADIS menerapkan strategi crossmedia dengan membagi hasil liputan menjadi tiga output yaitu laporan langsung pada Insta Story, tulisan di situs web, dan tulisan di cetak. Strategi cross-media juga dilakukan dengan melakukan distribusi informasi pada berbagai medium.

Pemanfaatan fitur Insta Story memberi sejumlah implikasi bagi Majalah GADIS yaitu sebagai teknologi yang efisien dan efektif, peningkatan jumlah kunjungan yang menjadi nilai tambah pada segi bisnis, komunikasi dengan khalayak lebih mudah, mendapatkan feedback yang kemudian dapat dijadikan sebagai bahan evaluasi, dan membuktikan kredibilitas Majalah GADIS sebagai sebuah media. Berdasarkan konsep ekonomi media, fitur Insta Story dapat dikatakan efisien karena tidak membebani cost production dan meningkatkan produktivitas. Nilai tambah pada segi bisnis berupa peningkatan jumlah kunjungan dari Insta Story juga merupakan bentuk terwujudnya tujuan dari strategi cross-media. Dianalisis menggunakan SCOT, anggota redaksi Majalah GADIS memiliki interpretasi atau pemaknaan yang sama terhadap Insta Story yaitu sebagai teknologi yang memiliki potensi membantu aktivitas jurnalistik mereka serta sebagai alat pembuktian eksistensi dan kredibilitas Majalah GADIS sebagai sebuah media di era digital.

\section{Daftar Pustaka}

APJII. (2018). Penetrasi \& Perilaku Pengguna Internet Indonesia Survey 2017. Teknopreneur, 2018(31 August 2018), Hasil Survey.

Bijker, W. E., Hughes, T. P., \& Pinch, T. (1993). The Social Construction of Technological Systems: New Directions in the Sociology and History of Technology. In The Social Constructions of Technological Systems.

Bogdan, R., \& Biklen, S. K. (2007). Qualitative research for education: An Introduction to theory and methods. In Qualitative research for education: An Introduction to theory and methods (5th Editio). Pearson.

Bungin, B. (2011). Penelitian Kualitatif: Komunikasi, Ekonomi, Kebijakan Publik, Dan Ilmu Sosial Lainnya. In Kencana. https://doi.org/10.1002/jcc.21776 
56 | Kajian Jurnalisme

ISSN 2549-0559 (cetak) ISSN 2549-1946 (online)

Volume 03 Nomor 01 Tahun 2019

Kawamoto, K. (2003). Journalism digital: emerging media and the changing horizons of journalism. In Journalism digital: emerging media and the changing horizons of journalism (pp. 1-29).

Kusuma, D. F., \& Sugandi, M. S. (2019). Strategi Pemanfaatan Instagram Sebagai Media Komunikasi Pemasaran Digital Yang Dilakukan Oleh Dino Donuts. Jurnal Manajemen Komunikasi, 3(1), 18. https://doi.org/10.24198/jmk.v3i1.12963

Moleong, L. J. (2017). Metodologi Penelitian Kualitatif (Edisi Revisi). In PT. Remaja Rosda Karya (Revision). https://doi.org/10.1016/j.carbpol.2013.02.055

Sumadiria, H. (2010). Jurnalistik Indonesia: Menulis Berita dan Feature. Bandung: Simbiosa Rekatama Media.

Tassel, J. Van, \& Poe-Howfield, L. (2010). Managing Electronic Media: Making, Marketing, and Moving Digital Content. In Taylor \& Francis (1st Editio). https://doi.org/10.1017/CBO9781107415324.004

Tempo.co. (2017, July). 45 Juta Pengguna Instagram, Indonesia Pasar Terbesar di Asia.

Tirto.id. (2017, April). Selamat Tinggal Generasi Milenial, Selamat Datang Generasi Z. Tirto.Id.

Usman, K. (2009). Ekonomi Media Pengantar Konsep dan Aplikasi. Bogor: Ghalia Indonesia. 